\title{
Do the Governmental Grants Influence in Breaching Free-market Competition? - The Data of SMEs Taken in Kosovo
}

\author{
Xhavit Islami \\ University of Prishtina, Faculty of Economics; Email: xhavit.islami@uni-pr.edu \\ Enis Mulolli \\ University of Prishtina, Faculty of Economics; Email: enis.mulolli@uni-pr.edu
}

Doi:10.5901/mjss.2016.v7n3p80

\begin{abstract}
This study used the data from fifty-six SMEs with the purpose to evaluate the role of governmental grants in increasing investments and profitablility of SMEs as well as the influence of grants in free market competition. The data were gathered with the help of a questionnaire. SMEs that have been supported with governmental grants realized their investment with cofinancing (one part of the project was financed with governmental grants, whereas the other part was financed by enterpreneurs with self-finances). The results showed that governmental grants as a method of public finances of SMES increased investment and profitability of supported SME, but also it influences in breaching the free competition. From finances of governmental grants are damaged non-supported SME of governmental grants that work the same acctivity as the supported enterprises by government. Governmental grants help a limited number of enterprises and the competition in between SME is not allowed to be regulated only with market forces that in the free-market competition decide which firms will stand or will get removed by the market based on their performance on the market. In the short-term period governmental grants keep "artificially" a number of SME in the market. This study argument what is most necessary to do for free market competition and presents the ideas of stable development and function of free-market economy.
\end{abstract}

Keywords: Governmental grants, investment, profitability, free competition, SMEs.

\section{Introduction}

The financing method is a challenge to be faced by the majority of small and medium enterprises in their start-up phase. The finances for new businesses can be achieved through four main resources: from personal savings, loans from family and friends, soft loans, supported grants from government or equity funding from venture capital institutions or informal investors (Alsos et al 2006; Foss \& Ljunggren, 2006; Borch et al, 2002). The financing method of SME is an important access for economy of market function and free competition in market. In Kosovo the governmental grants are applied as a method of financing to support SMEs to be grown and developed, in some economic sectors. In a form public financing with grants is an interference in trade economy. According to neo-classic theory the government interruption in market economy is necessary to reduce the problems related with market structure, the entry of firm in market and going out of the market, the problems with asymmetric and externality information (Johnson, S. 2005). The aspect of market structure, the entry problems and getting out of the market have a special importance for free competition function in the market. In academic literature are found a lot of studies that pointed out the role of governmental grants as a method of public financing for enterprises (David et al. 2000; Del Monte and Scalera 2001; Masso dhe Vildo 2006).

According to Girma et al (2003) the enterprises that have been supported with grants can use the advance technology, to raise the productivity as well as increases probability of surviving and creating places of work. According to principles of economy market, in practice it is very difficult to find an economy of free-market that functions in a perfect way, therefore there are cases that are shown like monopolist and oligopolistic market. It is worth mentioning that Johnson (2005), argumented the importance of grants for new enterprises increasement and suggested that new enterpreneurs must be supported with grants in start-up phase, in order for new firms to be offered the possibility of competing with existing enterprises in same conditions. Besides this, Bergström, (2000) pointed out that the state with public financing with grants makes attempts to equilibrate and to soft the impact of aglomerats in market polarisation created from forces of market failure. On the other hand, Lee (1996) claimed that in the industries supported from government, the competition is lower and the efficiency of the industry is reduced. Supporting SMEs with governmental 
grants is a case not ended, always there are different opinions of the way of distribution. Blomquist, S., \& L. Micheletto (2009) declares that grants system is often reformed and there is a continioues debate of how to be designed a grant system.

In this study our contribution will be for this case based on the gathered data of SMEs in Kosovo, through describing the investment growth and profitability of supported firms, and the influence of grants in breaching free-market competition.

\section{Study Objective}

Study objective is analyzing the influence of governmental grants in free-market competition. This analysis will be made through governmental grants evaluation as a method of public finances in investments increasment and benefited SMEs profitability. From SMEs tested that work in Kosovo, were taken data from 2013 (before taking grants) and 2014 (after getting governmental grants). The data of 2013 year served as a base on which are evaluated investment increasement and firms' profitability tested in 2014 year. And the impact of governmental grants in free-market competition.

\section{Theoretical Framework}

Related with the influence of governmental grants on free-market competition, there is lack of literature, but the focus will be in the literature that points out the impact of governmental grants as a method of public financing in increasing enterprise productivity. The majority of studies till now, offer information for social assistance format and governmental grants responsiblility in increasing the productivity and employment, supporting the R\&D programs, supporting the firms in the first phase of their creation (start-up), as well as the influence of grants in non-profitable organization (chairity). According to Girma et al (2003) the supporting objectives of government include the need to improve the access in SMEs in finances, to promote new businesses, to help the firms to have access, in new technologies or to reach the economic development of the place. Burki, A.A., (2015), points out that grants increase technique efficasity, profitability and employment in benefited firms. Increasing investments and SMEs profitability and the main indicators of their life-lasting in trade. A lot of authors have analyzed the impact of governmental grants in firm surviving. Vildo, S., Masso, J. (2009), showed that the influence of life term grants in enterprises, the norm of survivement of supported enterprises was higher than that of non-supported enterprises, for example in second year survived $77 \%$ of supported enterprises and $65 \%$ of non-supported enterprises.

According to Hubbard R.G. (1998), new firms and small firms to be faced with financial limitation therefore the government with the purpose to overthrow these limitations will offer help in the form of loans, it will low the rate of interest or cash grants. Crepon \& Duguet (2003), argumented that the enterprise support with subsvencions in start-up phase have raised in a way that surviving of firms and pointed out that the supporting effects of firms in start-up with subvention was stronger than with bank credits. Santarelli and Vivarelli (2002), through a model showed that the new firms do not have information in advance to show fundamental moment, meaning information about their efficacity relatively taken only after the enterprise is fundamented. After the entry in market, the enterprises must show that they have power to survive the market forces and to raise or otherwise if the enterprise is not effectively and must be removed from the market. Through this elaboration he raised the role of grants to support the new firms, through showing the double role that the subventions have to raise the norms of entering in new firms in the market and raise the norms of surviving the firms in the first years after start-up ${ }^{1}$. On the other hand, Vildo, S., Masso, J. (2009), argumented that startup grants influence positively in creating places of work but do not raise the chances of survivement of the firm. According to Kuusk \& Jürgenson (2007) in raport with Praxis research confirms that in Estonia grants for suppoting the firms in start-up phase is necessary and its functions are good. They also pointed out that the highest rate of firm survivement was two years after taking the grants $89 \%$ of firms survived.

Bergström (2000), has evaluated the impact of capital grants in productivity increasment in public sector in manufacturing industry in Sweden, results showed that grants are positively related with increasment of added-value.

The firm productivity is increased as a result of supporting with governmental grants (Almus and Prantl 2001;

\footnotetext{
1 Santarelli and Vivarelli (2002), pointed out that if the firm entry is considered as a process" try and see", subsvencions can cause huge deformation. From one side, the norms of huge entry can include eveb the number of early failure increase, and from the other side, the process of selecting trade is one side, through allowing the enterpreneuers lower efficasity to stand "artificially" in trade till the effect of subsvencion rests.
} 
Beaston and Weinstein, 19962; Czarnitzki and Fier 2002; Harris and Robinson, 2001). Grants as a method of public finances evaluate the convenient period of transition even Masso et al. (2007), described the period of transition, passing from a sociological place into a place with economy market, in this period the business sector is especially dynamic more in entry-exit that happen. From one side of new firms that enter in the market is more easy to position in a place with not developed industry whereas, on the other hand firms in start-up are demaged from undevelopment of economic institutions of market, limitation in capital and work in market, as well as, entrepreneurs without experience to lead a business in economy of market. Influence of grants in start-up phase for states with economy in trasition have been analyzed from (Burger et al. 2006).

For grants impact in reaching state cash has been dealt by authors: Lukason, O. and Masso, J., (2010), did a study with 39 firms. From this study they showed that enterprise support with grants in this way: whereas a lot of firms do not reach their purposes rapported (in circulation aspect, benefiting and creating places of work) and more than half of studied firms had taxes not payed dept evaluation for employees work in these firms have been higher compared with the sum of taken grants, then giving the grant has positively influenced in state fiscal cash.

From literature review is understood that governmental grants help benefited enterprises, through raising their productivity, equal are the results in our study where governmental grants have raised investments of benefited SMEs and have raised theor profitability. But "artificial" raise of supported firms with governmental grants put them not in equal positions with non-supported firms that work inside the same market competition.

\subsection{Survey hypothesis and question}

Based in literature review for grants' importance as a method of public financing, is pointed out that grants influence positively in benefited firm's productivity, therefore the hypothesis is raised whether this is worthy even for SMEs in Kosovo.

Hypothesis 1: Governmental grants are positively related with supported SMEs profitability.

Based on hypothesis 1 results, it is elaborated the impact of grants in free-market competition through answering research question.

Research question: Do governmental grants influence in breaching free-market competition.

\section{Methodological Approach}

To realize this study, a methodology consisting from a combination of primary and secondary data has been used. A considerable amount of secondary data has been used from existing literature of governmental grants, consulting important reports and researches for the impact of governmental grants in enterprise.

For the empirical analysis of the study, the data were gathered from a self-administered questionnaire. The questionnaire is articulated in that way to take data of SMEs for two periods of time, before and after taking the governmental grants. The participants were randomly choosen. From 70 questionnaires that were sent to the firms are taken back only 56 questionnaires (so the scale of responses was 80\%) from SMEs that have gained governmental grants, the data taken from questionnaire has been entered in regresion analysis. SMEs included in the study, their investment is made with co-financing, a part of the investment is made with public financing with grants and a part with self-finances. In question, In what did you invest the benefited money with grants? The response has been: Investment are made in objects, machinery and equipment, vehicles, lands, circulating capital. To measure the impact in between variables in this study SPSS v. 21 program has been used. Analysis is made from SMEs that work their activity in Kosovo in agrobusiness sector. Data analysed investments and profitability change of benefited SMEs with the purpose to evaluate governmental grants impact in their activity for a year period after taking grants from 2013 till 2014.

Bergostrom (2000), gave a response in question, how long should enterprises be monitored after taking grants? He has said that if monitored after a very short period of time exist the danger of not giving full raport of grant influence, whereas in long-period time is difficult to isolate the grant impact from other factors. Therefore, even their study results showed that in first year after giving grants supported firms are more productive, but later this productivity growth is

\footnotetext{
${ }^{2}$ Beaston and Weinstein, 2 Santarelli and Vivarelli (2002), pointed out that if the firm entry is considered as a process" try and see", subsvencions can cause huge deformation. From one side, the norms of huge entry can include eveb the number of early failure increase, and from the other side, the process of selecting trade is one side, through allowing the enterpreneuers lower efficasity to stand "artificially" in trade till the effect of subsvencion rests. (1996), made a study in Japan related with grants and found that the usage of industrial policy of assistance influenced in improvement of firm productivity.
} 
slowed in comparison with non-supported enterprises. Which means that governmental grants in sME long period loses force, the productivity of supported firms with grant from them non-supported is reduced.

\section{Empirical Foundings}

In table 1, are presented data of participants concerning demographic data such as: gender, education, age, their position in firm and their activity in the enterprise.

Table 1. Surveyors characteristics $(n=56)$

\begin{tabular}{|l|c|c|c|c|c|}
\hline Variable(s) & Frequency & \% age & Variable(s) & Frequency & \% age \\
\hline Gender & & & Age & & \\
\hline Male & 32 & 57.1 & $20-25$ years & 2 & 3.5 \\
\hline Female & 24 & 42.9 & $26-30$ years & 17 & 30.5 \\
\hline & & & $31-35$ years & 9 & 16.1 \\
\hline SME activity & & & $36-40$ years & 16 & 28.6 \\
\hline Trade & 42 & 75 & $41-45$ years & 4 & 7.1 \\
\hline Manufacturer & 14 & 25 & $46-50$ & 3 & 5.3 \\
\hline & & & Over 50 & 5 & 8.9 \\
\hline & & & & & \\
\hline Education & & & Position in Firm & & \\
\hline Intermediate & 30 & 53.6 & Owner & 40 & 71.4 \\
\hline Bachelors & 22 & 39.3 & Director & 7 & 12.5 \\
\hline Masters & 4 & 7.1 & Manager & 9 & 16.1 \\
\hline PhD & 0 & 0 & & & \\
\hline
\end{tabular}

Governmental grants increase the possibility of the firms to grow the investment and profitability, because from this method of financing exist more chances for more productivity of activity, trade services of benefiting firms. Apriory, in such a situation is translated in lowering the employment and increasing GDP in the place. This is only one side of the medal, for governmental grants. But, does such a situation influence the emotional part (lowering the motivation) and financial state of enterprenurs of non-benefited SMEs? It will be showed furtheron the study. So, the empirical analysis of governmental grants impact on benefiting firms is made and if this form of public financing damages non-profiable SMEs.

In research question: how percent have you raised investments in 2014 year in comparison with 2013 year? The response was $48 \%$ of participants declared to have double their investments, $12 \%$ declared that have tripled their investments, 29\% declared that they raised their investments four times more than in 2013 year and 11\% have responded that have raised investments five times more. In research question How much percent of your project is financed with grants? $10 \%$ declared that $50 \%$ of investment was financed with grants, $11 \%$ declared that $60 \%$ of investment was financed with grant, $54 \%$ declared that $65 \%$ of investment was financed with grants, $14 \%$ declared that $70 \%$ of investment was financed with grant and $11 \%$ declared that $75 \%$ of investment was financed with grants. Whereas, other part of financment is self-financed from enterpreneurs with self-finances (see graphic 2. in Appendix). From these answers is understood that each firm has benefited governmental grants has raised their investments in enterprise. Theoritically a growth of investments should result with firm productivity increase in the future. With the purpose evaluate the profitability of benefited enterprise of grants has been built (hypothesis 1) which will be presented below.

\section{Testing Hypothesis}

Hipothesis 1: Governmental grants are positively related with SMEs profitability.

According to regression analysis of independent variables "governmental grants" and enter in regression analysis through explaining $85.1 \%$ of dependent variable "profitability".

Results showed that the model is statistically important counted with Fisher value, $F(1.54)=314,095$ and $p=000$ for level control 0.05 because $(0.000<0.5)$. $T$ - test from this analysis regists $(t=17.723, p=0.000)$, that showed that independent variable is statistically important which means that regression coefficient is different from zero. Negative value of non-standardized coeficients B, showed that if "governmental grant" are zero SMEs profitability will be negative 
for $-3949.345 \mathrm{E}$, if other variables remain unchanged. Results of regression analysis showed that $\mathrm{B}$ is bigger than zero (B1 = 3.676) therefore hypothesis $\mathrm{H} 1$ is accepted. (see table 2) bellow:

Through using non-standardized weight of regression the regression equation is multiplied can be presented as

$$
\begin{aligned}
& \hat{Y}=\beta_{0}+\beta_{1} X_{1}+\varepsilon \\
& \hat{Y}=\text { dependent variable "Profitability" } \\
& \beta_{0}=\text { non-standardized coefficients (constant) } \\
& \beta_{1}=\text { non-standardized coefficient of variable "governmental grants" } \\
& X_{1}=\text { independent variable "Grants" } \\
& \varepsilon=\text { standard error. }
\end{aligned}
$$

Table 2. Analysis of linear regression for dependent variable "Profitability"

\begin{tabular}{|l|c|c|c|c|c|c|c|c|}
\hline Modeli & $\mathrm{R}$ & $\mathrm{R}^{2}$ & Adjusted R2 & $\mathrm{B}$ & Std. Error & Beta & $\mathrm{t}$ & Sig. \\
\hline & .924 & .853 & .851 & & & & & \\
\hline Constant & & & & -3949.345 & 10227.927 & & -.386 & .701 \\
\hline (Governmental grants) & & & & 3.676 & .207 & .924 & 17.723 & .000 \\
\hline
\end{tabular}

\subsection{Research question: Do governmental grants influence in breaching free-market competition?}

In this paragraph will be represented an analysis of how governmental grants influences in free-market competition based on results of the below analysis in which is argumented that financed firms with governmental grants have raised the investments and have increased profitability.

But, to evaluate the impact of governmental grants in free-market competition, firstly should be analysed the impact of grants in lowering the cost of benefiting SMEs.

If the question is asked: Do investments of supported firms by grants lower the cost? The answer is understood from answering the previous question: How many percent of your project is financed with grants? A response from $50 \%$ till $75 \%$ of their investment is realized with public financing (with grant), therefore is understood that even the cost of invesments is from $50 \%-75 \%$ lower than the real cost of their investment. Lowering cost of investmen means productivity of enterprise increases because financed SMEs with grant, curve of total cost will be situated bellow (for investments sum financed with grant), through representing huger profitability.

In curve 1, graphically is presented the investment of a firm that is supported with grant, in cost point of view. In curve 2, is presented the investment of a firm that is not supported with grant, in cost point of view. According to gathered data with questionnaires, the firms participated in the study showed that $50 \%-75 \%$ of their project is financed with grant. Curves 1 , has been built to show if a firm has invested a predetermined sum in order to realize their project, it has invested with its self equipment only $25 \%-50 \%$ of this sum. Whereas, the other sum is supported with public financing by grants. In curve 2, is represented a firm investment that is not supported with grants and the cost of investment is covered from eneterprise that writes as enterprise cost. This method of support of SMEs that can not be financed with grants all firms that work their activity in Kosovo, offers different creation in between SMEs that are supported with grant and the ones that are not supported, through damaging the last ones. In curves 1 and 2, is showed that the state with their policies for SMEs support influence in free-market competition through not letting that competing predetermined forces, the level of investment of a firm.
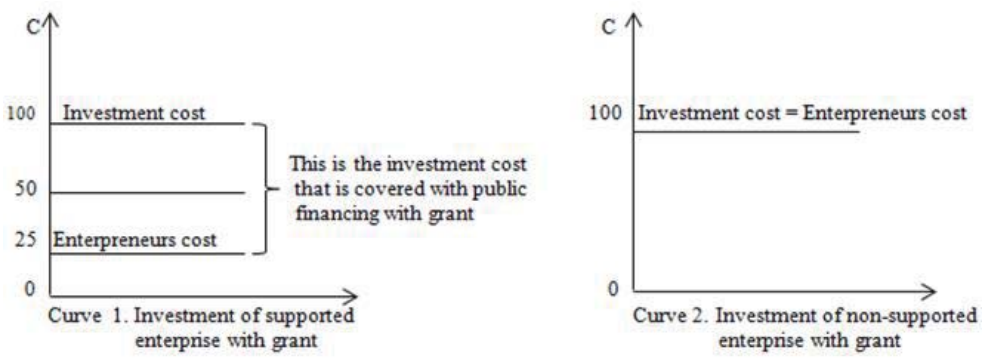
The method of investment with self-financing means tha all kinds of financment that are barrier for enterpreneurs, the money that enterpreneurs invest can be saved earlier or can be borrowed with the purpose of giving back later. So, supported SMEs with governmental grants increases productivity as a result of lowering the cost of investment.

In this case benefited SMEs of governmental grants can work in two ways:

1. To realize a higher benefit - their products are sold with the same price with the market, but to realize even higher benefits than other firms that sell the same products which are not supported with grants.

2. To lower the price of products- supported firms can in the same time to lower the price products with the purpose to attract new consumators. Consumator's growth is translated in product increase $\rightarrow$ entry increase $\rightarrow$ growth of profit. Supporting SMEs with governmental grants directly raises their profitability in short-term period. Whereas in long-term period this impact goes continouesly to decrease.

Through pointing out that governmental grants as a method of public financing are applied and are convenient in places not enough economically developed with the purpose to support creation, increasment and SMEs survivement. In the time of globalization where function the international economy of free market protectionism is not an alternative (through putting tariffs and quotes for imported products), for enterprise support and local products because is in contrary with free market rules. Therefore, state policies should find other methods to support enterprises with the purpose that local products to make competition with imported products. So, grants as a financing method in Kosovo can argument their role in creating conditions for national enterprise to export and to compete with foreign firms. But, even besides that this form of public financing can not be applied for all enterprises that need this support through creating favoriztion for some enterprise and through not creating for some other, some firms can be financed, whereas, some others not. However, national firms can be damaged more than do not benefit governmental grants and exactly here can be noticed the influence of state in supporting some SMEs and damaging some others that are not supported, but damaged as a financing consequence of competing firms from the side of state.

\section{Conclusion}

In this study the data gathered from 56 SMEs which have financed their investments with grants, in order to evaluate the impact of governmental grants in increasing investment and enterprises' profitability of the supported enterprises as well as their impact in breaching free-market competition. Results showed that studied SMEs in 2014, $48 \%$ of the supported enterprises doubled investments in comparison with 2013, 12\% tripled, 29\% raised their investment four times and $11 \%$ have increased their investments five times more than in 2013. This increase of investments is supported from $50 \%$ till $75 \%$ with governmental grants whereas the other part is financed with self-finances. Also, supported SMEs have increased their profitability as a result their cost lowering. The distribution of governmental grants favourizes only some SME, not all SMEs of the same kind, this not balanced from state side is defined as an impact in free competition in the market and decides the competing firms in not balanced position of the same market. However, the firms that take governmental grants are less than the firms that do not take it, results that grants distribution is a wrong policy of the state to raise and develop SMEs. From governmental grants distribution are demaged non-suported SMEs that work the same activity as supported SME by government. Results of the study showed that giving the selective grants only for some SMEs, influences in lowering the opportunities of entering in the market the new firms, whereas increases the possibility of failure of enterprises not supported with grants in start-up phase, as a result of supporting competing SMEs from the state. This study arguments it which is important for competition of free market and presents the idea of stable development of economic function of the market. Therefore, this study makes a significant contribution to the scientific and academic value, for the impact of governmental grants in the free-market competition in Kosovo, in the region and beyond ${ }^{3}$.

\section{Recommandation}

Recommandations that are given in this study are based in the results of this study and using existing literature national and internaltional raports as well as in developed state to support SMEs. That aimed the application of financing method that do not influence in the free-market competition in Kosovo. Eventhough the government follows the financing policy with governmental grants for improvement and development of SMEs in Kosovo, with the purpose to be faced with competition of foreign firm's products that come as imported in Kosovo, foreign firms can have facilities from policies of

\footnotetext{
${ }^{3}$ Remarks: The investment government quantity is not opposite in SMe, but governmental grans as a method of financing from
} government. 
their places therefore can come with very competing prices with which prices can be damaged national producers. Besides this purpose, this method of supporting is not fair therefore from this form can not benefit all national firms.

- Therefore alternative methods are suggested for public financing and SMEs supporting in Kosovo, as supporting SMEs with soft loans, credits guarantation, start-up loans, so to offer programs for support where all firms of an economic sector can have the same access.

- SMEs should be supported with free training for entrepreneur, in order for the new enterpreneurs to have chance to be consulted to overthrow the business challenges.

- The state must invest in business infrastructure, to plan stimulated fiscal policies. It is recommended the model. (see figure 1).

\section{Study Limitations}

This study contributes in literature richment related with governmental grants but it has its limitation. The study limitations are:

- The number of chosen SMS that participated in the study is low (56). For this reason, it must be payed attention in the attempt to generalize the data of this study.

- The data for supported SMEs with governmental grants are gathered in a moment in time only for 2014 year, not in different periods of time (the data of 2013 year are taken before the SMEs took the governmental grants, which are gathered with the purpose to evaluate the growth of SMEs after governmental grants). The value of the study would have been higher if the data were gathered in different periods of time with the purpose of following dynamics for the influence of governmental grants in increasing investment and profitability of a SME as well as in breaching the free-market competition.

\section{References}

Almus, M., \& Prantl, S. (2001). "Die Auswirkungen öffentlicher Gründungsförderung auf das Überleben und Wachstum junger Unternehmen" (No. 01-03). ZEW Discussion Papers.

Alsos, G. A., Isaksen, E. J., \& Ljunggren, E. (2006). "New venture financing and subsequent business growth in men-and women-led businesses". Entrepreneurship theory and practice, vol. 30(5), pp. 667-686.

Beason, R. and D.E. Weinstein (1996) "Growth, economies of scale, and targeting in Japan (1955-1990)". Review of Economics and Statistics, vol. 78, pp. 286-295.

Bergström, F. (2000). "Capital Subsidies and the Performance of Firms". Small Business Economics, vol. 14, pp. 183-193.

Blomquist, S., and L. Micheletto (2009). "Nonlinear income taxation and matching grants in a federation with decentralized in-kind transfers". International Economic Review, vol.50(2), pp. 543-575.

Borch, O. J., Isaksen, E., Jenssen, S. A., Kolvereid, L., Sørheim, R., \& Widding, L. Ø. (2002). "Kapitalmarked for nyetablerte bedrifter: en studie av etterspørsels-og tilbudssiden". KPB-rapport. Bodø, Handelshøgskolen i Bodø og bedriftsforskning Kunnskapsparken AS-Bodø.

Burger, A., Jaklic, A., Rojec, M. (2006), "Dynamic effects of R\&D subsidies in Slovenia: Substitute or Complement to Private R\&D Expenditures", University of Ljubljana, mimeo.

Burki, A. A. (2015). "Group-based BDS matching grants and farm-level outcomes in Pakistan". Journal of Development Effectiveness, vol. 7(1), pp.43-63.

Crépon, B., \& Duguet, E. (2003). Bank loans, start-up subsidies and the survival of the new firms: an econometric analysis at the entrepreneur level. Start-up Subsidies and the Survival of the New Firms: An Econometric Analysis at the Entrepreneur Level.

Czarnitzki, D., Fier, A., (2002). "Do innovation subsidies crowd out private investment:evidence from the German service sector". Applied Economics Quarterly. Vol.48 (1), pp 1-25.

David, P. A., Hall, B., Toole, A. A. (2000). "Is public R\&D a complement or a substitute for private R\&D? A review of the econometric evidence?". Research Policy, Vol. 29, pp. 497-529.

Del Monte, A., Scalera, D. (2001). "The Life Duration of Small Firms Born Within a Start-up Programme: Evidence from Italy". Regional Studies, Vol. 35, pp. 11-21.

Foss, L. \& Ljunggren, E. (2006). "Women's entrepreneurship in Norway: Recent trends and future challenges. In C.G. Brush, N.M. Carter, E.J. Gatewood, P.G. Greene, \& M.M. Hart (Eds.), Growth-oriented women entrepreneurs and their businesses-A global research perspective (pp. 154-182). Cheltenham, UK: Edward Elgar.

Girma, S., Gorg, H., \& Strobl, E. (2003). Government grants, plant survival and employment growth: A micro-econometric analysis.

Harris, R., \& Robinson, C. (2001, October). "The impact of regional selective assistance on UK manufacturing total factor productivity, 1990-98". In CEPR/ESRC Workshop, London.

Hubbard, R.G. (1998) "Capital market imperfections and investment", Journal of Economic Literature, Vol. 36, pp. 193-225.

Johnson, S. (2005, November). SME Support Policy: Efficiency, Equity, Ideology or Vote-Seeking. In Proceedings of the Institute of 
Small Business and Entrepreneurship (ISBE) Conference, Blackpool, UK.

Kuusk, K., \& Jürgenson, A. (2007). "Riiklike ettevõtluse tugimeetmete mõjude hindamine. Koondraport".

Lee, J.-W. (1996). "Government Interventions and Productivity Growth", Journal of Economic Growth, Vol. 1, pp. 391-414.

Lukason, O., \& Masso, J. (2010). "Performance of selected Estonian firms financed with start-up grant: ability to follow plans and grant usage efficiency". EESTI MAJANDUSPOLIITILISED VÄITLUSED, 253.

Masso, J., \& Vildo, S. (2006). The government grants to enterprises: theoretical arguments and the possibilities to measure their efficiency. In 14th Scientific Conference on Economic Policy (pp. 521-542).

Masso, J., Eamets, R., \& Philips, K. (2007). "Creative Destruction and Transition: Evidence on Firm Demographics from Estonia". Entrepreneurship, Industrial Location and Economic Growth, Edward Elgar, pp. 81-103.

Santarelli, E., \& Vivarelli, M. (2002). "Is subsidizing entry an optimal policy?" Industrial and Corporate Change, vol.11(1), pp. 39-52.

Vildo, S., \& Masso, J. (2009). "The impact of start-up grants on firm performance in Estonia". Discussions on Estonian economic policy: Theory and practice of economic policy, 17.

\section{Appendix}

Graphic 1. Investment of asked firms for 2013 and 2014

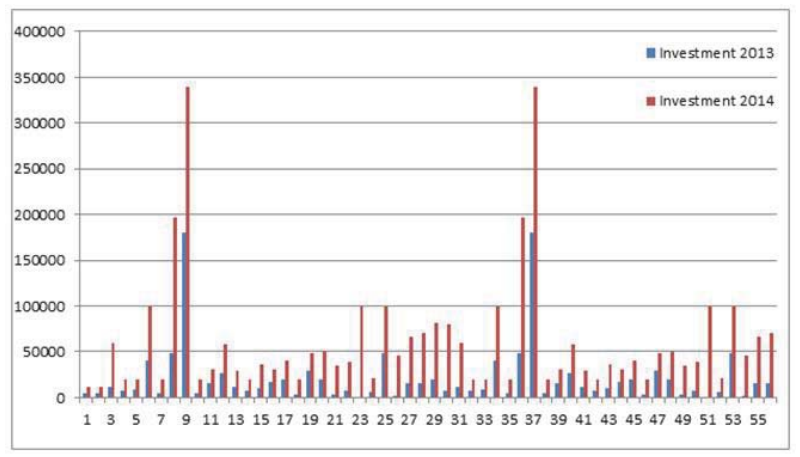

Graphic 2. Investment according to financing method for 2014

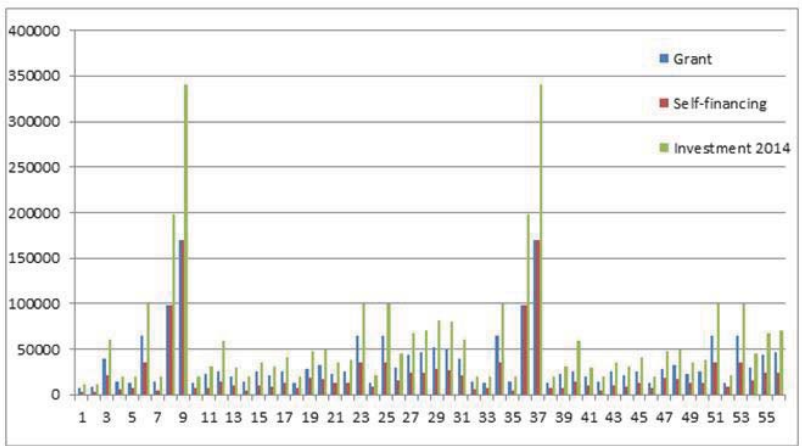




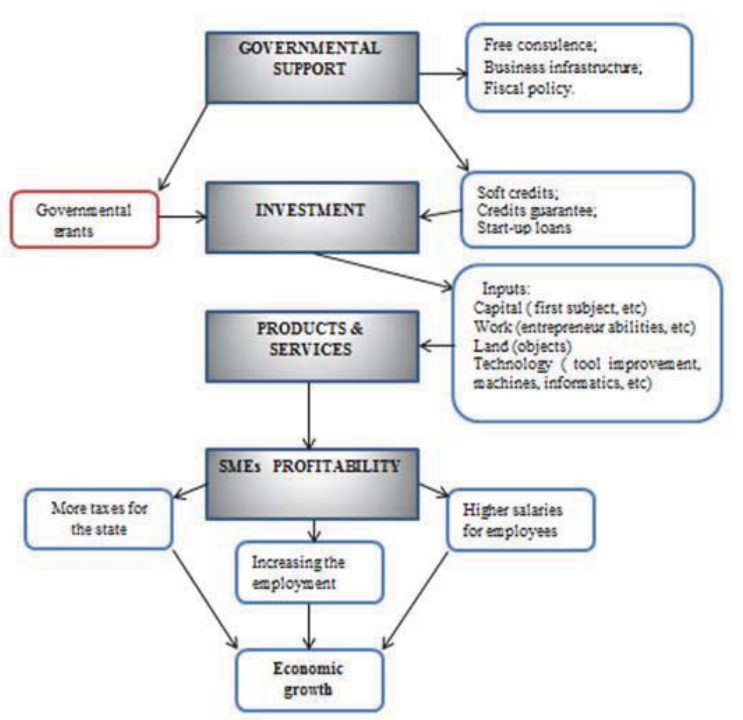

Figure 1. Conceptual model, government-support-investment-profitability-economic growth

Conceptual model has assured an average raise of economy in the place. As can be seen in the figure 1, governmental grants are entered in red frame ${ }^{4}$, that means the results of this study do not support this method of financing from governmental idea for SMEs.

\footnotetext{
${ }^{4}$ Remarks: Governmental grants must be applied only in cases when there has monopolistic market, with the purpose to raise the
} competition in the market from which the society as a total. 